\title{
Identification of Legacy and Active Sources of Metal Contamination in Soils in Brooklyn, NY
}

\author{
Emily Henderson \\ City University of New York School of Public Health \\ Andrew Maroko \\ City University of New York School of Public Health \\ Elizabeth Kelvin \\ City University of New York School of Public Health \\ Brian Pavilonis ( $\sim$ brian.pavilonis@sph.cuny.edu) \\ CUNY School of Public Health: City University of New York School of Public Health https://orcid.org/0000-0001-5065-3710
}

\section{Research Article}

Keywords: Urban pollution, Metal contamination, Metal exposure, Brooklyn, NY, Soil contamination

Posted Date: February 7th, 2022

DOI: https://doi.org/10.21203/rs.3.rs-1324719/v1

License: (c) (7) This work is licensed under a Creative Commons Attribution 4.0 International License. Read Full License 


\section{Abstract}

The purpose of this study was to examine the spatial distribution and potential anthropogenic sources of $\mathrm{Pb}, \mathrm{Zn}, \mathrm{Cu}, \mathrm{Mn}$, and Fe in surface soils throughout Brooklyn, NY. We collected soil samples $(n=1,373)$ from 176 different New York City parks. Metal concentrations were analyzed ex-situ using a portable X-ray fluorescence with a subset $(n=350)$ confirmed with ICP-MS. The effect of multiple sources on metal concentrations were determined by stepwise multivariable linear regression with generalized estimating equations. Median concentrations for $\mathrm{Pb}, \mathrm{Zn}, \mathrm{Cu}, \mathrm{Fe}$, and $\mathrm{Mn}$ were 107.8 ppm, 144.7 ppm, 49.4 ppm, 14033.6 ppm, and 279.2 ppm, respectively. All metals were significantly correlated with one another $(p<0.001)$, with the strength of the correlation ranging from a low of approximately $\rho=0.3(P b-\mathrm{Mn}$ and $\mathrm{Zn}-\mathrm{Mn})$ to a high of $\rho=0.7(\mathrm{~Pb}-\mathrm{Cu})$. In final multivariate modeling, scrap yards were significantly associated with $\mathrm{Mn}$ concentration $(\beta=0.075$, $0.019)$, NPL sites was significantly associated with $P b, F$ and $M n(\beta=0.134, p=0.004 ; \beta=0.038, p=0.014 ; \beta=0.057, p=0.037$, respectively), and bridges nearby were significantly associated with $\mathrm{Pb}$ and $\mathrm{Zn}(\beta=0.106, \mathrm{p}=0.003 ; \beta=0.076, \mathrm{p}=0.026$, respectively). Although manufacturing and industry have mostly left the area, smaller scrap metal recyclers are abundant and significantly increased $\mathrm{Cu}$ and $\mathrm{Mn}$ soil concentrations. In addition, NPL sites contributed to increased concentrations of all five metals within $800 \mathrm{~m}$. Roadways have long been established to be sources of urban pollution; however, in our study we also found the presence of bridges within $800 \mathrm{~m}$ were also strongly predictive of increased $\mathrm{Pb}, \mathrm{Cu}$, and $\mathrm{Zn}$ concentrations.

\section{Introduction}

Soil is a sink for anthropogenic metal pollution ${ }^{1,2}$ that often requires remediation to reduce exposure to the surrounding community. ${ }^{3,4}$ Anthropogenic metals in soil are generally more bioavailable than natural sources, which increases adsorption and body burden. ${ }^{3}$ Contaminated soil can expose urban populations via resuspension, especially during dry summer periods. ${ }^{5,6}$ Consequently, children's blood lead levels (BLL) were found to be significantly higher in dry summer months in an area with widespread Pb contaminated soil. ${ }^{7}$ Soil metal levels can also serve as indicators of active environmental pollution generated within the community.

Like many urban areas within the United States (U.S.), Brooklyn, New York (NY) was once home to a vast manufacturing and industrial sector that has largely ceased operations. Although, these operations have left the borough the legacy of environmental metal contamination continues to expose residents. ${ }^{8,9}$ In the 1800 s, factories opened along Brooklyn's East River waterfront that propelled it to become one of the nation's leading manufacturers of processed goods. Coal was used to power many of these factories, releasing metals into the environment. ${ }^{9,10}$ Sugar refining was the largest industry in Brooklyn, but other major industries included shipbuilding and repair, oil and gas refining, glass and pottery making, book publishing, and cast iron manufacturing; and at the turn of the twentieth century, $\mathrm{Pb}$ smelters and incinerators operated in parts of Brooklyn. ${ }^{10}$ In addition to industrial and manufacturing metal sources, various types of debris were used to fill marshlands, raise land elevation, and expand waterfront property in Brooklyn. This fill was composed of materials containing metals and may account for the spatial heterogeneity in metals concentration throughout the borough. ${ }^{11}$ Over the past 20 years, industrial and manufacturing land has been rezoned and a large influx of new residents have migrated to areas of Brooklyn that have a history of contamination sources that may lead to continued contamination and exposure risk among residents. ${ }^{12}$

Metals such as zinc $(\mathrm{Zn})$, copper $(\mathrm{Cu})$, manganese $(\mathrm{Mn})$, and iron $(\mathrm{Fe})$ are essential nutrients that are required for various biochemical and physiological functions, but can exhibit an " $\mathrm{U}$ " shaped dose response relationship. ${ }^{13} \mathrm{Lead}(\mathrm{Pb})$, on the other hand, is a toxic metal with no biological requirement in humans nor exposure threshold for harm. ${ }^{14}$ Exposure to high concentrations of all five metals are associated with various negative health effects ranging from neurological to immunological. High levels of $\mathrm{Mn}$ exposure can cause irreversible neurological disease, including behavioral changes and a lowered IQ as well as a condition called manganism that presents with symptoms similar to Parkinson's. ${ }^{15-19}$ Occupational inhalation exposure to $\mathrm{Zn}$ has long been known to cause metal fume fever, which is characterized by acute influenza like symptoms. ${ }^{20,21}$ Long-term exposure to Cu dust can cause upper respiratory irritation, ${ }^{22}$ while high Fe exposure can increase the risk of cancer through the generation of free radicals. ${ }^{23}$ All organ systems in the body are negatively affected by the cumulative exposure to $\mathrm{Pb}$, regardless of the exposure route, and $\mathrm{Pb}$ exposure can result in adverse effect to the neurologic and nervous system, slowed growth and development, and learning and behavior problems. The neurological effects linked to Pb exposure, including a lowered IQ and behavioral changes, appear to be permanent. ${ }^{24-28}$

While most exposure assessments look at exposure to individual metals, there are potential additive and synergistic health effects from exposure to multiple harmful metals (metal mixtures), including oxidative stress, cardiovascular, and neurological effects. ${ }^{29-31}$ Metal mixtures can disrupt the blood brain barrier and induce a synergistic toxicity in astrocytes. ${ }^{30}$ Short-term inhalation exposure to urban particulate matter laden with multiple metals was associated with increased systemic inflammation and oxidative stress. ${ }^{29}$ Increased fetal exposure to metal mixtures has also been associated with oxidative stress and congenital heart disease..$^{31,32}$ 
A previous study conducted by some of the authors on this paper found an ecological association between high soil Pb levels and increased rates of elevated pediatric BLLs in Brooklyn. ${ }^{33}$ This study seeks to expand upon that finding and characterize the spatial distribution and identify potential active and legacy sources of $\mathrm{Pb}, \mathrm{Zn}, \mathrm{Cu}, \mathrm{Mn}$, and Fe in surface soils in Brooklyn, NY. Identifying key sources of metal contamination can help predict areas with elevated metal levels and direct the implementation of programs designed to mitigate risk to residents.

\section{Methods}

\section{Soil Sampling}

Between June 15 through August 15, 2020, we collected soil samples ( $n=1,373)$ from 176 different New York City Department of Parks and Recreation properties (NYC Parks), which included community parks, neighborhood parks, and triangles/plazas. Soil measurements were collected in a grid pattern when possible. However, the greenspaces in this study were unevenly shaped polygons with obstructions such as hard surfaces, playground equipment, and water. As a result, the sampling schemes were adjusted in the field as necessary. Sample locations were recorded and the ESRI ArcGIS Collector (Redlands, California) was used to manage the location data.

The parks where sampling took place varied in size, with areas ranging from 4.05 to $876,771 \mathrm{~m}^{2}$. In parks larger than $100,000 \mathrm{~m}^{2}, 30$ samples were taken per park; in parks between $10,000 \mathrm{~m}^{2}$ and 100,000 $\mathrm{m}^{2}$, a median of 14 samples (between 7 and 30 samples) were taken; in parks between $1,000 \mathrm{~m}^{2}$ and $10,000 \mathrm{~m}^{2}$, a median of four samples (between 1 and 8 samples) were taken; and in community parks and plazas less than $1,000 \mathrm{~m}^{2}$, one sample was collected.

\section{Soil Analyses with pXRF}

For each soil sample, 50-200 grams were collected at 0-5 cm depth with a clean trowel and transferred to a clean Zip-lock plastic bag. Each sample was screened for $\mathrm{Pb}, \mathrm{Cu}, \mathrm{Zn}, \mathrm{Mn}$, and Fe concentrations ex-situ with a portable X-ray fluorescence (pXRF) instrument (Thermo Scientific Niton, model XL3t) set to soil mode. A 30 second exposure time was used for each measurement, which was taken directly on each sample bag containing soil. Prior to each use, a system check was carried out on the instrument, and before each sampling session, a series of soil standards reference materials, produced by The United States Geological Survey (USGS) and the National Institute of Standards and Technology (NIST), were measured with the pXRF. These measurements had to fall within 2 standard deviations (SD) of the reference value. If a reading fell outside 2 SD but within $3 \mathrm{SD}$, another reading was needed and, if acceptable, data collection could start. If the reading was not acceptable, a system recheck was needed. The certified values for $\mathrm{SiO}_{2}$ blank, NIST 2709a, NIST 2780, and USGS SdAR-M2 can be seen in Table 1. The limit of detection (LOD) for each metal was calculated from 1.5 times the precision of the measurement, which was unique for each measurement and two times the SD. ${ }^{34}$ The LODs ranged from 11.5 to $19.3 \mathrm{ppm}$ for $\mathrm{Pb}(\mathrm{n}=31)$, 28.8 to $68.4 \mathrm{ppm}$ for $\mathrm{Cu}(\mathrm{n}=232), 79.2$ to $127.4 \mathrm{ppm}$ for $\mathrm{Mn}(\mathrm{n}=13)$, and 19.7 to $23.6 \mathrm{ppm}$ for $\mathrm{Zn}(\mathrm{n}=2)$. No Fe readings were below the LOD.

Table 1

Certified values for soil standard reference materials

\begin{tabular}{|llllll|}
\hline \multicolumn{5}{|c|}{ Certified Values (ppm) } \\
\hline Soil Standard Reference Material & $\mathrm{Pb}$ & $\mathrm{Mn}$ & $\mathrm{Zn}$ & $\mathrm{Cu}$ & $\mathrm{Fe}$ \\
\hline $\mathrm{SiO}_{2}$ & 0 & 0 & 0 & 0 & 0 \\
\hline NIST 2709a & $17.3 \pm 0.1$ & $529 \pm 18$ & $103 \pm 4$ & $33.9 \pm 0.5$ & $33,600 \pm 700$ \\
\hline USGS SdAR-M2 & $808 \pm 14$ & $*$ & $760 \pm 13$ & $236 \pm 4$ & * \\
\hline NIST 2780 & $5,770 \pm 410$ & $462 \pm 21$ & $2,570 \pm 160$ & $215.5 \pm 7.8$ & $27,840 \pm 800$ \\
\hline *Metal was not in the soil standard reference material & & & \\
\hline
\end{tabular}


Table 2

Agreement between ICP-MS and pXRF by metal

\begin{tabular}{|llll|}
\hline Metal & Slope $(\mathbf{m g} / \mathbf{k g})$ & $\mathbf{r}^{2}$ & Mean relative \% difference \\
\hline $\mathrm{Pb}$ & 0.976 & 0.94 & 7.5 \\
\hline $\mathrm{Zn}$ & 0.913 & 0.90 & 30.4 \\
\hline $\mathrm{Cu}$ & 0.890 & 0.91 & 15.9 \\
\hline $\mathrm{Fe}$ & 0.752 & 0.95 & 35.5 \\
\hline $\mathrm{Mn}$ & 0.735 & 0.88 & 35.5 \\
\hline
\end{tabular}

\section{Confirmation Laboratory Analyses with ICP-MS}

A subset of samples $(n=350)$ were validated using inductively coupled plasma mass spectrometry (ICP-MS) analyses. Samples were first dried to constant weight at $105^{\circ} \mathrm{C}$, disaggregated using a mortar and pestle, and then sieved to less than $2 \mathrm{~mm}$. Approximately $0.3 \mathrm{~g}$ of this fine fraction was acid digested using a microwave oven digester following the US Environmental Protection Agency (EPA) Method 3051. ${ }^{35}$ The digested samples were then analyzed for metals using an ICP-MS (Perkin Elmer, Elan DRCe) at Brooklyn College (EPA Method 6020). Results from the ICP-MS analyses corroborated the findings obtained with the pXRF, with high degree of agreement between the methods, although the pXRF did slightly underestimate metal concentrations. The slope, $\mathrm{r}^{2}$, and mean relative percent difference for each metal are show in Table 3.

Table 3

Descriptive statistics for soil concentrations (ppm) stratified by metal

\begin{tabular}{|llllllll|}
\hline Metal & Mean & Standard Deviation & Median & 25th Percentile & 75th Percentile & Minimum & Maximum \\
\hline $\mathrm{Pb}$ & 143.1 & 141.9 & 107.8 & 60.8 & 179.5 & 7.6 & 1839.6 \\
\hline $\mathrm{Zn}$ & 187.9 & 194.1 & 144.7 & 105.4 & 212.1 & 13.1 & 4826.7 \\
\hline $\mathrm{Cu}$ & 61.3 & 42.8 & 49.4 & 35.4 & 70.0 & 19.2 & 505.2 \\
\hline $\mathrm{Fe}$ & 14269.1 & 4268.0 & 14033.6 & 11852.3 & 16407.6 & 1366.1 & 48545.1 \\
\hline $\mathrm{Mn}$ & 295.3 & 170.6 & 279.2 & 218.5 & 350.9 & 52.8 & 4826.8 \\
\hline
\end{tabular}

\section{Potential Sources of Metal Contamination}

We investigated several potential sources of metals in the soil: scrap yards, National Priorities List (NPL) sites, Toxic Release Inventory (TRI) facilities, bridges, manufacturing/industrial land use, new construction, above-ground subway routes, and roads. The influence of these sources on metal concentrations in soil samples were operationalized in two ways. For relatively uncommon features (e.g., scrap yards), a binary approach using fixed-distance buffers was employed (i.e., the soil sample was "near" or "not near" the source). For features which are relatively common or ubiquitous (e.g., roads, industrial land use) a continuous approach using either kernel density estimation (KDE; varying intensities based on density of the potential source) or simple linear density (e.g., miles of roadway per unit area) were used. ERSI ArcGIS (ArcMap version 10.7.1 and Pro version 2.8.3) was used for geospatial analyses.

The binary approach was applied to scrap yards, National Priorities List (NPL) sites, Toxic Release Inventory (TRI) sites, and bridges. We created an indicator for "scrap yard" that included: steel fabricators, scrap metal recycling centers, scrap metal dealers, salvage yards, household waste recyclers, and construction waste recycling centers. Scrap yards were located via Google Maps and geocoded. Proximity buffers of $400 \mathrm{~m}(\sim 1 / 4$ mile) were then created to identify nearby soil samples. NPL and TRI sites were downloaded from the US Environmental Protection Agency (EPA), geocoded, and filtered to the study area. ${ }^{36}$ Data on bridges were acquired by selecting only the appropriate features from the NYC Department of City Planning's Linear Integrated Ordered Network (LION) dataset via the NYC Open Data portal. ${ }^{37}$ Distance buffers of $800 \mathrm{~m}(\sim 1 / 2$ mile) were generated to characterize soil sample proximity to each of the NPL, TRI, and bridge features. Buffer distance was selected based on overall size of the facility and identification by the EPA. ${ }^{38}$

The continuous approach was applied to industrial/manufacturing land uses, new construction (since 2010), above-ground subway routes, and roads. Information about roads was derived from the LION dataset ${ }^{37}$ with densities calculated as linear length of all roadways within a $400 \mathrm{~m}$ buffer of each sample location divided by the area of the buffer. Tax lots where (1) the building class is manufacturing and industrial land use, as well as (2) new construction since 2010 were extracted from the Primary Land Use Tax Lot Output (MapPLUTO) dataset and 
downloaded via NYC Open Data. ${ }^{37}$ A continuous KDE surface was produced to quantify the density of new construction and industrial/manufacturing land use. It was parameterized using an $800 \mathrm{~m}$ bandwidth using building area as the "intensity" value (i.e., larger building area results in higher density estimates). Above-ground subway routes were derived from subway route and station data collected from the Baruch College Geoportal. ${ }^{39}$ Routes were considered to be "above ground" if they were between two stations which were "at grade" or "elevated". Routes between one above-ground and one below-ground station were bisected, with the section closer to the above-ground station designated as "above ground". These were then converted into KDE surfaces using the same parameterization as the tax lots, however without an added "intensity" value (i.e., it is simply the length of the subway route which impacts the resulting density values).

\section{Statistical Analyses}

Metal concentration data were right skewed and therefore log-transformed (base 10) to better approximate a normal distribution and confirmed from QQ plots. We assessed the bivariate associations among variables using Spearman Rank Order correlations for two numeric variables (e.g. the correlation between the five metals and between each metal with numeric predictors) and the Wilcoxon signedrank test to determine the significance of differences in the metal levels by categorical predictor variables.

We assessed the association between each metal and hypothesized contamination sources using backwards stepwise multivariable linear regression with generalized estimating equations (GEE) to adjust for clustering of soil samples, since multiple samples were collected at most parks. All independent variables were included in the initial model and the variable with the largest $p$-value was removed and the model rerun repeatedly until all variables left had $p$-values<0.20. Data analyses were conducted using SAS statistical software (version 9.4 , Cary, NC).

\section{Results}

Generalized spatial trends of metal concentrations are shown in Figure 1. The highest metal levels were observed along the periphery of Brooklyn, in the North along the East River waterfront, in the Southwest, and in the East. Metal concentrations were highly right skewed, with two to three orders of magnitude difference between the minimum and maximum concentration for all five metals. Iron was found in the greatest abundance, while soil Cu concentrations were the lowest. Median concentrations for Pb, Zn, Cu, Fe, and Mn were 107.8 ppm, 144.7 ppm, 49.4 ppm, 14033.6 ppm, and 279.2 ppm, respectively (Table 3). All metals were significantly correlated with one another ( $<<0.001)$, with the strength of the correlation ranging from a low of approximately $\rho=0.3$ (Pb-Mn and $\mathrm{Zn}-\mathrm{Mn}$ ) to a high of $\rho=0.7$ (Pb-Cu) (Table 4$)$. 
Table 4

Unadjusted associations for continuous and categorical variables

\begin{tabular}{|c|c|c|c|c|c|c|c|c|c|c|c|}
\hline \multirow[t]{2}{*}{ Variable } & \multirow{2}{*}{$\begin{array}{l}\text { Total } \\
\mathrm{n}\end{array}$} & \multicolumn{2}{|l|}{$\mathrm{Pb}$} & \multicolumn{2}{|l|}{ Zn } & \multicolumn{2}{|l|}{$\mathrm{Cu}$} & \multicolumn{2}{|l|}{$\mathrm{Fe}$} & \multicolumn{2}{|l|}{ Mn } \\
\hline & & Measure & $\begin{array}{l}\mathrm{P} \text { - } \\
\text { value }\end{array}$ & Measure & $\begin{array}{l}\mathrm{P} \text { - } \\
\text { value }\end{array}$ & Measure & $\begin{array}{l}\mathrm{P} \text { - } \\
\text { value }\end{array}$ & Measure & $\begin{array}{l}\mathrm{P}- \\
\text { value }\end{array}$ & Measure & $\begin{array}{l}\mathrm{P}- \\
\text { value }\end{array}$ \\
\hline $\mathrm{Pb}, \mathrm{S}_{\mathrm{p}}$ & 1373 & 1 & & 0.60 & $<0.001$ & 0.66 & $<0.001$ & 0.54 & $<0.001$ & 0.32 & $<0.001$ \\
\hline $\mathrm{Zn}, \mathrm{Sp}$ & & 0.60 & $<0.001$ & 1 & & 0.60 & $<0.001$ & 0.39 & $<0.001$ & 0.32 & $<0.001$ \\
\hline $\mathrm{Cu}, \mathrm{S}_{\mathrm{p}}$ & & 0.66 & $<0.001$ & 0.60 & $<0.001$ & 1 & & 0.47 & $<0.001$ & 0.36 & $<0.001$ \\
\hline $\mathrm{Fe}, \mathrm{S}_{\mathrm{p}}$ & & 0.54 & $<0.001$ & 0.39 & $<0.001$ & 0.47 & $<0.001$ & 1 & & 0.64 & $<0.001$ \\
\hline$M n, S_{p}$ & & 0.32 & $<0.001$ & 0.32 & $<0.001$ & 0.36 & $<0.001$ & 0.64 & $<0.001$ & 1 & \\
\hline $\begin{array}{l}\text { Manufacturing/ } \\
\text { Industrial } \\
\text { Density, Sp }\end{array}$ & & 0.08 & 0.004 & 0.19 & $<0.001$ & 0.25 & $<0.001$ & 0.16 & $<0.001$ & 0.13 & $<0.001$ \\
\hline $\begin{array}{l}\text { Road density, } \\
S_{p}\end{array}$ & & 0.28 & $<0.001$ & 0.28 & $<0.001$ & 0.28 & $<0.001$ & 0.11 & $<0.001$ & 0.03 & 0.266 \\
\hline $\begin{array}{l}\text { Subway } \\
\text { Density, Sp }\end{array}$ & & -0.01 & 0.617 & 0.02 & 0.573 & -0.04 & 0.129 & 0.05 & 0.082 & $<0.01$ & 0.944 \\
\hline $\begin{array}{l}\text { Construction } \\
\text { density, Sp }\end{array}$ & & 0.03 & 0.214 & 0.16 & $<0.001$ & 0.20 & $<0.001$ & 0.07 & 0.007 & 0.02 & 0.438 \\
\hline \multicolumn{12}{|l|}{$\begin{array}{l}\text { NPL, median } \\
(\mathrm{ppm})\end{array}$} \\
\hline Yes & 43 & 102.2 & 0.588 & 155.9 & 0.008 & 67.1 & $<0.001$ & 15021.3 & 0.125 & 313.9 & 0.036 \\
\hline No & 1330 & 107.8 & & 144.2 & & 49.0 & & 13990.0 & & 278.3 & \\
\hline \multicolumn{12}{|l|}{ TRI } \\
\hline Yes & 631 & 113.9 & $<0.001$ & 160.8 & $<0.001$ & 56.5 & $<0.001$ & 14421.1 & 0.003 & 284.3 & 0.075 \\
\hline No & 742 & 105.1 & & 135.2 & & 44.5 & & 13844.6 & & 277.6 & \\
\hline \multicolumn{12}{|l|}{ Scrap yard } \\
\hline Yes & 77 & 131.4 & 0.170 & 181.1 & 0.001 & 74.9 & $<0.001$ & 15625.8 & $<0.001$ & 333.8 & $<0.001$ \\
\hline No & 1296 & 107.0 & & 143.8 & & 48.7 & & 13933.6 & & 277.2 & \\
\hline \multicolumn{12}{|l|}{ Bridge } \\
\hline Yes & 440 & 147.0 & $<0.001$ & 165.4 & $<0.001$ & 58.0 & $<0.001$ & 14446.0 & 0.008 & 282.2 & 0.310 \\
\hline No & 933 & 94.9 & & 140.7 & & 46.4 & & 13898.1 & & 278.0 & \\
\hline
\end{tabular}

Manufacturing/industrial land density and road density were significantly correlated with the five metals, with the strength ranging from $\rho=$ 0.08 (manufacturing/industrial density with $\mathrm{Pb}$ ) to $\rho=0.28$ (road density with $\mathrm{Pb}, \mathrm{Cu}$, and $\mathrm{Zn}$ ). The only exception was the correlation between road density and $\mathrm{Mn}$, which was not significant. There was a significant positive correlation between construction density and $\mathrm{Zn}$, $\mathrm{Cu}$, and Fe $(\rho=0.16 ; \rho=0.20 ; \rho=0.07$, respectively). Subway density was not significantly correlated with any of the metals. In addition, the concentration of $\mathrm{Pb}$ was significantly higher in areas near TRI facilities and bridges (median concentrations: 113.9 ppm versus $105.1 \mathrm{ppm}$, $\mathrm{p}<0.001 ; 147.0 \mathrm{ppm}$ versus $94.9 \mathrm{ppm}, \mathrm{p}<0.001$, respectively), as was $\mathrm{Fe}(14421.1 \mathrm{ppm}$ versus $13844.6 \mathrm{ppm}, \mathrm{p}=0.003 ; 14446.0$ ppm versus $13898.1 \mathrm{ppm}, \mathrm{p}=0.008$, respectively). Copper concentration was significantly higher in locations near NPL and TRI sites, scrap yards, and bridges (Median concentration: 67.1 ppm versus 49.0 ppm, $p<0.001 ; 56.5$ ppm versus 44.5 ppm, $p<0.001 ; 74.9$ ppm versus 48.7 ppm, $\mathrm{p}<0.001 ; 58.0 \mathrm{ppm}$ versus $46.4 \mathrm{ppm}, \mathrm{p}<0.001$, respectively), as was $\mathrm{Zn}$ concentration (median concentration: $155.9 \mathrm{ppm}$ versus $144.2 \mathrm{ppm}$, $\mathrm{p}=0.008 ; 160.8 \mathrm{ppm}$ versus $135.2 \mathrm{ppm}, \mathrm{p}<0.001 ; 181.1 \mathrm{ppm}$ versus $143.8 \mathrm{ppm}, \mathrm{p}=0.001 ; 165.4 \mathrm{ppm}$ versus $140.7 \mathrm{ppm}, \mathrm{p}<0.001$, respectively). Mn concentration was significantly higher near NPL sites and scrap yards (median concentration: 313.9 ppm versus 278.3 ppm, $\mathrm{p}=0.036 ; 333.8 \mathrm{ppm}$ versus $277.2 \mathrm{ppm}, \mathrm{p}<0.001$, respectively) (Table 4). 
In the final backwards stepwise multivariable regression model, all predictor variables were positively associated with log-transformed metal concentrations except new building construction density which was significantly negatively associated with $\mathrm{Pb}(\beta=-2.51 \mathrm{E}-08$, $p=0.030)$ and $\mathrm{Cu}(\beta=-1.23 \mathrm{E}-08, \mathrm{p}=0.022)$. Road density was significantly associated with $\mathrm{Pb}(\beta=0.008, p<0.001), \mathrm{Cu}(\beta=0.005, \mathrm{p}<0.001), \mathrm{Zn}$ $(\beta=0.005, p=0.026)$, and $\mathrm{Fe}(\beta=0.004, p<0.001)$ concentrations. Manufacturing/industrial density was significantly associated with $\mathrm{Cu}, \mathrm{Zn}$, and $\mathrm{Fe}(\beta=1.44 \mathrm{E}-08, p=0.035 ; \beta=1.58 \mathrm{E}-08, p=0.048 ; \beta=1.15 \mathrm{E}-08 ; p=0.014$, respectively). Above subway density was significantly associated with $\mathrm{Pb}$ and $\mathrm{Zn}$ concentration $(\beta=0.047, \mathrm{p}=0.042 ; \beta=0.028, \mathrm{p}=0.027$, respectively). Scrap yards were significantly associated with $\mathrm{Mn}$ concentration $(\beta=0.075,0.019)$ and NPL sites was significantly associated with $\mathrm{Pb}, \mathrm{Fe}$ and $\mathrm{Mn}(\beta=0.134, p=0.004, \beta=0.038$, $p=0.014 ; \beta=0.057, p=0.037$, respectively). Finally, bridges nearby were significantly associated with $P b$ and $Z n(\beta=0.106, p=0.003 ; \beta=$ $0.076, p=0.026$, respectively) (Table 5).

Table 5

Multivariable linear regression models looking at the adjusted association between metal concentrations (log transformed) and nearby potential sources of contamination

\begin{tabular}{|c|c|c|c|c|c|c|c|c|c|c|}
\hline \multirow[t]{2}{*}{ Variable } & \multicolumn{2}{|l|}{$\mathrm{Pb}$} & \multicolumn{2}{|l|}{$\mathrm{Cu}$} & \multicolumn{2}{|l|}{$\mathrm{Zn}$} & \multicolumn{2}{|l|}{$\mathrm{Fe}$} & \multicolumn{2}{|l|}{$\mathrm{Mn}$} \\
\hline & Beta & $p$ & Beta & $p$ & Beta & $p$ & Beta & $p$ & Beta & $p$ \\
\hline Road density & 0.008 & $<0.001$ & 0.005 & $<0.001$ & 0.005 & 0.026 & 0.004 & $<0.001$ & 0.002 & 0.053 \\
\hline $\begin{array}{l}\text { Manufacturing/ } \\
\text { Industrial } \\
\text { Density }\end{array}$ & - & - & $\begin{array}{l}1.44 \mathrm{E}- \\
08\end{array}$ & 0.035 & $\begin{array}{l}1.58 \mathrm{E}- \\
08\end{array}$ & 0.048 & $\begin{array}{l}1.15 \mathrm{E}- \\
08\end{array}$ & 0.014 & $\begin{array}{l}8.23 \mathrm{E}- \\
09\end{array}$ & 0.095 \\
\hline Construction density & $\begin{array}{l}-2.51 \mathrm{E}- \\
08\end{array}$ & 0.030 & $\begin{array}{l}-1.23 \mathrm{E}- \\
08\end{array}$ & 0.022 & - & - & $\begin{array}{l}-8.09 \mathrm{E}- \\
09\end{array}$ & 0.053 & $\begin{array}{l}-8.20 \mathrm{E}- \\
09\end{array}$ & 0.062 \\
\hline Above ground subway density & 0.047 & 0.042 & - & - & 0.028 & 0.027 & - & - & - & - \\
\hline $\begin{array}{l}\text { Scrap yard within } 400 \text { meters } \\
\text { (ref=none within } 400 \text { meters) }\end{array}$ & - & - & 0.043 & 0.065 & - & - & - & - & 0.075 & 0.019 \\
\hline TRI* & - & - & - & - & - & - & 0.025 & 0.149 & - & - \\
\hline NPL* & 0.134 & 0.004 & 0.073 & 0.084 & 0.090 & 0.132 & 0.038 & 0.014 & 0.057 & 0.037 \\
\hline Bridge* $^{\star}$ & 0.106 & 0.003 & 0.046 & 0.101 & 0.076 & 0.026 & - & - & - & - \\
\hline - = not significant & & & & & & & & & & \\
\hline${ }^{*}$ ref=none within 800 & & & & & & & & & & \\
\hline
\end{tabular}

\section{Discussion}

The objective of this study was to investigate the spatial distribution and identify potential anthropogenic sources of $\mathrm{Pb}, \mathrm{Zn}, \mathrm{Cu}, \mathrm{Mn}$, and $\mathrm{Fe}$ contamination in surface soils throughout parks and greenspaces in Brooklyn, NY. Median concentrations of $\mathrm{Pb}, \mathrm{Zn}$, and Cu were

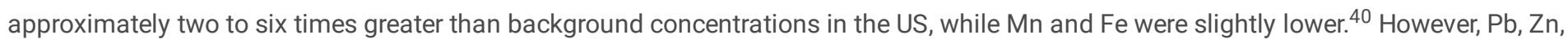
and $\mathrm{Cu}$ concentrations were similar, or in some cases a bit lower, than what was found in other soil characterization studies conducted in large urban areas, including in Chicago, IL (Pb=198 ppm; $\mathrm{Zn}=235$ ppm; $\mathrm{Cu}=59$ ppm), ${ }^{41}$ New Orleans, LA (Pb=656 ppm; Zn=373 ppm; Cu median $=32 \mathrm{ppm}),{ }^{42}$ and Syracuse, NY $(\mathrm{Pb}=130.0 \mathrm{ppm} ; \mathrm{Zn}=178.7 \mathrm{ppm}) .{ }^{43}$ In our study we found that metal concentrations were highest along the periphery of Brooklyn near the waterways.

Roadway density and the presence of bridges within $800 \mathrm{~m}$ were strongly predictive of increased $\mathrm{Pb}, \mathrm{Cu}$, and $\mathrm{Zn}$ concentrations. In urban areas, roadway proximity has long been an environmental justice issue with racial minority groups or low-income households more likely to live in the vicinity of high volume roadways. ${ }^{44}$ Increased metal concentrations observed in this study are likely a combination of legacy and active sources. Lead was a gasoline additive for most of the 20th century until it was banned for use in on-road vehicles in $1996 .{ }^{45}$ However, $\mathrm{Pb}$-based paint is still used on steel coatings such as bridges. ${ }^{46}$ Copper and $\mathrm{Zn}$ are released into the environment through brake pad abrasion and tire wear, while $\mathrm{Zn}$ is used as an oil additive. ${ }^{2}$ Elevated bridges likely disperse traffic-generated particulates over a greater distance as well as serve as potential source itself. In NYC, there have recently been proposals to cap a major bridge, located in a disadvantage area, to reduce air pollution to the surrounding community. ${ }^{47}$ 
The U.S. EPA designates NPL sites to guide further investigation due to active release or threatened release of pollutants into the environment. ${ }^{48}$ In multivariate models, all metal concentrations increased in the vicinity of a NPL sites. Adjusting for significant co-variates, $\mathrm{Pb}$ concentrations increased by $27 \%$ (139.8 versus 102.6 ppm) within $800 \mathrm{~m}$ of a NPL, while Zn concentrations increased by $23.1 \%$ (206.1 versus $167.4 \mathrm{ppm})$. Like roadways, proximity to NPL sites disproportionately effects low-income resident ${ }^{49}$ and pollutants contained within hazardous waste sites can migrate to residential homes. A study of homes located within $800 \mathrm{~m}$ a hazardous waste had $27 \%$ greater $\mathrm{Pb}$ and $43 \%$ greater Zn concentrations in house dust compared to home outside the $800 \mathrm{~m}$ buffer. ${ }^{50}$ Remediation of NPL sites needs to consider the surrounding area as pollution can migrate offsite and potentially contaminate residential zoned land.

We identified twenty scrap metal recyclers operating in Brooklyn, many of which were in dense residential neighborhoods. Soil samples collected within $400 \mathrm{~m}$ of scrap yards had increased $\mathrm{Cu}$ and $\mathrm{Mn}$ concentrations even after controlling for other likely sources. At scrap metal recyclers, the metals are broken down by torch cutting, shredding, shearing, or crushing, usually in open scrap yard spaces. As a result, metal laden particulate may be transported into the surrounding community through the air and deposited onto soil. A study conducted in Houston, TX observed increased concentrations of Fe, nickel (Ni), chromium ( $\mathrm{Cr}$ ), $\mathrm{Mn}$ and Pb particulates in the vicinity of metal recyclers. ${ }^{51}$ In our analysis, Fe was associated with scrap yards in the crude association but not after adjusting for other potential sources of metals while $\mathrm{Pb}$ was not significantly associated with scrap yards in the crude or unadjusted associations; however, our data was non-specific and did not take into account the type of metals processed at the facility or wind direction.

There were several limitations in this study. There may have been some measurement error since we only collected samples from publicly accessible spaces, and our definition of potential sources may be inaccurate as we did not take into consideration wind patterns and the built environment which could impact the direction in which pollutants spread and where they accumulate. This measurement error, however, is likely non-differential, which would attenuate associations. Additionally, some of the associations may have been underpowered, especially for weaker associations, leading to type 2 error (failing to reject the null hypothesis when it is not true) and we looked at five different metals but did not adjust our alpha for multiple comparisons, which could have led to type 1 errors (rejecting the null when it is true). Furthermore, we did not collect data on all potential sources of metal contamination, which may have led to residual confounding. Soil samples were only collected from publicly accessible spaces and did not include residential soil samples. A previous NYC study found significantly lower Pb concentrations in community garden soils compared to home garden soils, likely the result of tillage and soil replacement. ${ }^{1}$ Thus our findings cannot be generalized to soil in other types of greenspace, such as private gardens, which could be important sources of exposure. Future studies should consider including greenspaces and other soils not included here (e.g., lawns of public housing, private and semi-private spaces, etc.) in their sampling methodology. Finally, Brooklyn, NY may differ in important characteristics from other boroughs of NYC and from other cities, and therefore results of this study may not be generalizable to other locations.

\section{Conclusions}

Metal contamination throughout Brooklyn, NY is widespread and from a combination of legacy and active sources. This study found elevated levels of $\mathrm{Pb}, \mathrm{Cu}, \mathrm{Fe}, \mathrm{Mn}$, and $\mathrm{Zn}$ along the periphery of the borough and in the North along the East River waterfront where there are legacy sources of metal contamination. Although large manufacturing and industry have mostly left the area, smaller scrap metal recyclers are abundant and significantly increased $\mathrm{Cu}$ and $\mathrm{Mn}$ soil concentrations. In addition, NPL sites contributed to increased concentrations of all five metals within $800 \mathrm{~m}$ of the site. Roadways have long been established to be sources of urban pollution; however, in our study we also found the presence of bridges within $800 \mathrm{~m}$ were strongly also predictive of increased $\mathrm{Pb}, \mathrm{Cu}$, and $\mathrm{Zn}$ concentrations. Additional studies are needed to assess the health impacts and develop programs to protect the residents near and visitors of these green spaces.

\section{Declarations}

\section{Funding}

This publication was supported in part by Grant Number, T420H008422, funded by the Centers for Disease Control and Prevention. Its contents are solely the responsibility of the authors and do not necessarily represent the official views of the Centers for Disease Control and Prevention or the Department of Health and Human Services. Additional support was provided by a PSC-CUNY Award [63782-00 51, 2020], funded jointly by The City University of New York and The Professional Staff Congress.

\section{Acknowledgements}

The authors of this paper wish to thank Ms. Johana Melendez Garcia and Mr. Anselem Okorie for their assistance with sample collection and preparation. 


\section{References}

1. Cheng Z, Paltseva A, Li I et al (2015) Trace metal contamination in New York City garden soils. Soil Sci 180(4/5):167-174

2. Sager M (2020) Urban Soils and Road Dust-Civilization Effects and Metal Pollution-A Review. Environments 7(11):98

3. Hou D, O'Connor D, Nathanail P, Tian L, Ma Y (2017) Integrated GIS and multivariate statistical analysis for regional scale assessment of heavy metal soil contamination: A critical review. Environ Pollution 231:1188-1200

4. Wong CS, Li X, Thornton I (2006) Urban environmental geochemistry of trace metals. Environ pollution 142(1):1-16

5. Laidlaw MA, Filippelli GM, Sadler RC, Gonzales CR, Ball AS, Mielke HW (2016) Children's blood lead seasonality in flint, Michigan (USA), and soil-sourced lead hazard risks. Int J Environ Res public health 13(4):358

6. Li I, Cheng Z, Paltseva A, Morin T, Smith B, Shaw R (2016) Lead in New York city soils. Paper presented at: International Conference on Landscape Architecture to Support City Sustainable Development

7. Zahran S, Laidlaw MA, McElmurry SP, Filippelli GM, Taylor M (2013) Linking source and effect: Resuspended soil lead, air lead, and children's blood lead levels in Detroit, Michigan. Environ Sci Technol 47(6):2839-2845

8. Fecht S (2017) High levels of lead contaminate many backyards in Brooklyn neighborhood. https://news.climate.columbia.edu/2017/10/09/many-backyards-in-brooklyn-neighborhood-are-contaminated-with-high-levels-of-lead/. Accessed September 1, 2021

9. North Brooklyn Neighbors (2021) A brief history of North Brooklyn. https://northbrooklynneighbors.org/eli/. Published n.d. Accessed September 1,

10. Brooklyn Legends (2021) A brief history of Brooklyn. https://brooklynlegends.com/a-brief-history-of-brooklyn/. Published n.d. Accessed September 1,

11. North Brooklyn Neighbors (2021) Strengthening our common ground: Lead in soil in Greenpoint.

https://northbrooklynneighbors.org/project/strengthening-our-common-ground-lead-in-soil-in-greenpoint/. Published n.d. Accessed September 1,

12. Pavilonis B, Maroko A, Cheng Z (2020) Lead in New York City's soils: Population growth, land use, and contamination. Int J hygiene Environ health 229:113564

13. Organization WH (1996) Trace elements in human nutrition and health. World Health Organization

14. Abadin H, Ashizawa A, Llados F, Stevens (2007)Y-W. Toxicological profile for lead.

15. Davis J, Jarabek A, Mage D, Graham J (1999) Inhalation health risk assessment of MMT. Environ Res (New York NY: Print) 80(2):103104

16. Mergler D (1999) Neurotoxic effects of low level exposure to manganese in human populations. Environ Res 80(2):99-102

17. Silbergeld EK (1999) Science and policy. Environ Res (New York NY: Print) 80(2):93-95

18. Zayed J, Vyskocil A, Kennedy G (1999) Environmental contamination and human exposure to manganese-contribution of methylcyclopentadienyl manganese tricarbonyl in unleaded gasoline. Int archives Occup Environ health 72(1):7-13

19. Neal AP, Guilarte TR (2013) Mechanisms of lead and manganese neurotoxicity. Toxicol Res 2(2):99-114

20. Roney N (2005) Toxicological profile for zinc. Agency for Toxic Substances and Disease Registry

21. Graeme KA, Pollack CV Jr (1998) Heavy metal toxicity, part II: lead and metal fume fever. J Emerg Med 16(2):171-177

22. Dorsey A, Ingerman $L$ (2004) Toxicological profile for copper.

23. Guo W, Zhang J, Li W, Xu M, Liu S (2015) Disruption of iron homeostasis and resultant health effects upon exposure to various environmental pollutants: A critical review. J Environ Sci 34:155-164

24. Lanphear BP, Hornung R, Khoury J et al (2005) Low-level environmental lead exposure and children's intellectual function: an international pooled analysis. Environ health Perspect 113(7):894-899

25. Koller K, Brown T, Spurgeon A, Levy L (2004) Recent developments in low-level lead exposure and intellectual impairment in children.Environmental health perspectives.:987-994

26. Dietrich KN, Douglas RM, Succop PA, Berger OG, Bornschein RL (2001) Early exposure to lead and juvenile delinquency. Neurotoxicology and teratology 23(6):511-518

27. Bandeen-Roche K, Glass TA, Bolla KI, Todd AC, Schwartz BS (2009) The longitudinal association of cumulative lead dose with cognitive function in community-dwelling older adults. Epidemiol (Cambridge Mass) 20(6):831

28. Canfield RL, Henderson CR Jr, Cory-Slechta DA, Cox C, Jusko TA, Lanphear BP (2003) Intellectual impairment in children with blood lead concentrations below $10 \mu \mathrm{g}$ per deciliter. New Engl J Med 348(16):1517-1526

Page 9/11 
29. Liu L, Urch B, Szyszkowicz M et al (2018) Metals and oxidative potential in urban particulate matter influence systemic inflammatory and neural biomarkers: A controlled exposure study. Environ Int 121:1331-1340

30. Rai A, Maurya SK, Khare P, Srivastava A, Bandyopadhyay S (2010) Characterization of developmental neurotoxicity of As, Cd, and Pb mixture: synergistic action of metal mixture in glial and neuronal functions. Toxicol Sci 118(2):586-601

31. Liu Z, He C, Chen M et al (2018) The effects of lead and aluminum exposure on congenital heart disease and the mechanism of oxidative stress. Reproductive Toxicol 81:93-98

32. Kundak AA, Pektas A, Zenciroglu A et al (2017) Do toxic metals and trace elements have a role in the pathogenesis of conotruncal heart malformations? Cardiol Young 27(2):312-317

33. Pavilonis B, Cheng Z, Johnson G, Maroko A (2021) Lead, Soils, and Children: An Ecological Analysis of Lead Contamination in Parks and Elevated Blood Lead Levels in Brooklyn, New York.Archives of environmental contamination and toxicology.:1-10

34. Thermo, Scientific NITON XL3t 500 Analyzer User's Guide. Verson 6.5.

35. Agency UEP (2003) EPA Method 3051: microwave acid assisted digestion of sediments, sludges, soils and oils. In: US EPA Washington, DC

36. US Environmental Protection Agency. Envirofacts. https://enviro.epa.gov/. Published 2020. Updated November 22 (2021) Accessed January 27, 2022

37. New York City Department of City Planning (2022) PLUTO and MapPLUTO. https://www1.nyc.gov/site/planning/data-maps/opendata/dwn-pluto-mappluto.page. Published 2022. Accessed January 27,

38. Maantay JA, Maroko AR, Porter-Morgan H (2008) Research note-A new method for mapping population and understanding the spatial dynamics of disease in urban areas: Asthma in the Bronx, New York. Urban Geogr 29(7):724-738

39. Baruch College. Baruch Geoportal Home. https://www.baruch.cuny.edu/confluence/display/geoportal/. Accessed

40. Smith D, Cannon W, Woodruff L, Solano F, Kilburn J, Fey D (2013) Geochemical and mineralogical data for soils of the conterminous United States: US Geological Survey Data Series 801. In:US Department of the Interior, US Geological Survey Location Reston, VA;

41. Cannon W, Horton JD (2009) Soil geochemical signature of urbanization and industrialization-Chicago, Illinois. USA Appl Geochem 24(8):1590-1601

42. Mielke HW, Wang G, Gonzales CR, Powell ET, Le B, Quach VN (2004) PAHs and metals in the soils of inner-city and suburban New Orleans, Louisiana, USA. Environ Toxicol Pharmacol 18(3):243-247

43. Hunt A, Johnson D, Griffith D, Zitoon S (2012) Citywide distribution of lead and other element in soils and indoor dusts in Syracuse, NY. Appl Geochem 27(5):985-994

44. Rowangould GM (2013) A census of the US near-roadway population: Public health and environmental justice considerations. Transp Res Part D: Transp Environ 25:59-67

45. Newell RG, Rogers K (2003) The US experience with the phasedown of lead in gasoline.Resources for the Future.:32

46. Gottesfeld P (2015) Time to ban lead in industrial paints and coatings. Front public health 3:144

47. Adam Kuperstein. New Proposal Would Replace BQE With Tunnel, Open Up Brooklyn Bridge Park. https://www.nbcnewyork.com/traffic/transit-traffic/new-proposal-would-replace-bqe-with-tunnel-open-up-brooklyn-bridgepark/2301108/. Published 2020. Updated February 25, 2020 Accessed

48. US EPA, Superfund (2021) : National Priorities List (NPL). https://www.epa.gov/superfund/superfund-national-priorities-list-npl. Published 2021. Updated February 8, Accessed December 30, 2021

49. Burwell-Naney K, Zhang H, Samantapudi A et al (2013) Spatial disparity in the distribution of superfund sites in South Carolina: an ecological study. Environ Health 12(1):1-11

50. Zota AR, Schaider LA, Ettinger AS, Wright RO, Shine JP, Spengler JD (2011) Metal sources and exposures in the homes of young children living near a mining-impacted Superfund site. J exposure Sci Environ Epidemiol 21(5):495-505

51. Han I, Richner D, An Han H, Hopkins L, James D, Symanski E (2020) Evaluation of metal aerosols in four communities adjacent to metal recyclers in Houston, Texas, USA. J Air Waste Manage Association 70(5):568-579

\section{Figures}

\section{Figure 1}

Page $10 / 11$ 
Metal concentrations in soil. Continuous surfaces of metal concentration estimates extrapolated from sample locations (bottom right map) using empirical Bayesian Kriging. All estimates are shown in deciles (first decile is lightest shade; $10^{\text {th }}$ decile is darkest shade). Note that the surfaces were created for the visualization of generalized spatial trends and were not used for statistical analyses. 